\title{
Stosunek legalizmu prawnego
} do Bożej sprawiedliwości w świetle Mt 5, 20

Prawodawstwo izraelskie poprzez wieki ulegało rozmaitym zmianom i modyfikacjom. Szeroko rozpowszechnione zostały zwyczajowe przepisy, obecne także w zbiorach prawnych innych ludów starożytnych. Kodeks prawny Izraela różnił się jednak od pozostałych reguł starożytnych tym, że regulował głównie stosunki narodu względem JHWH. Można wyraźnie zauważyć, że prawodawstwo narodu wybranego odnosi się o wiele bardziej do życia religijnego niż cywilnego. Ponadto cała legislacja pochodziła od Boga ${ }^{2}$. Kodeks Prawa w Izraelu, zwany Torą, stanowił Przymierze Boga i człowieka oraz regulował stosunki ludzi między sobą.

Przestrzeganie Prawa w Izraelu było równoważne z uznaniem podmiotu prawnego za sprawiedliwy. Pojawiały się jednak spory o interpretacje reguł lub wzajemne zobowiązania ludzi wobec siebie. Potrzeba więc było administratorów sprawiedliwości. Już w Księdze Wyjścia przeczytamy, jak to sam Mojżesz stawał się sędzią w sporach międzyludzkich (Wj 18, 13-27). Z czasem normy religijne stały się także

\footnotetext{
1 Kapłan archidiecezji krakowskiej, doktorant w Katedrze Hermeneutyki Biblijnej i Judaistyki UPJPII w Krakowie.

2 Por. R. de Voux, Instytucje Starego Testamentu, t. 1 i 2, tłum. T. Brzegowy, Poznań 2004, s. 169.
} 
kodeksem królewskim i za panowania Artakserksesa Prawo Boże, które przyniósł Ezdrasz, ustanowiono równocześnie jurydycznym porządkiem państwa (Ezd 7, 26).

Normy były niestety wielokrotnie przekraczane przez lud. Sprawiedliwość Boża nie pozwoliła się jednak ograniczyć ludzką niesprawiedliwością. Łamanie przez ludzi Przymierza nie spowodowało wyrzeczenia się ludu przez Boga ani bezpowrotnego odrzucenia go, choć z punktu widzenia legalizmu stanięcie w opozycji wobec Prawa powodowało zerwanie umowy. Ten, kto przekraczał normy, mógł zostać ukarany, równocześnie powinny mu zostać odebrane wszystkie przywileje związane z zawartym paktem. Sprawiedliwość Boża przekroczyła jednak legalizm prawny, a winny wykroczeń przeciw Prawu zostawał poddany pod „sąd miłosierdzia”. Należy pamiętać, że pojęcie „sprawiedliwość” staje "ramię w ramię" z miłością, która niepomiernie przewyższa normatywne rozumienie sprawiedliwości ${ }^{3}$.

\section{Znaczenie rdzenia צדק wiblii hebrajskiej}

Zarówno termin „sprawiedliwość”, jak i pojęcie „prawość” pochodzą od tego samego hebrajskiego rdzenia ${ }^{4}$. Różne jego formy, zarówno rzeczownikowe, jak i czasownikowe, w swoim podstawowym znaczeniu określają tego, kto okazał się wierny i prawdziwy, sprawdził się. Takie znaczenie dotyczy przede wszystkim kontekstu prawnego. Właśnie dlatego synonimem sprawiedliwości staje się niewinność wobec Prawa, która ma charakter moralny ${ }^{5}$. Biblijne określenie „sprawiedliwy” oznacza więc tego, kto wypełnia Prawo. Stąd wniosek, że mówienie

\footnotetext{
3 Por. A. M. Sicari, Sprawiedliwość Boża w Starym Testamencie, „Communio” 1 (1981) nr 1-2, s. 50.

4 Ideę sprawiedliwości w Biblii hebrajskiej najlepiej oddają słowa pochodzące od rdzenia צִ צִdq), które pojawiają się 523 razy w Starym Testamencie. Por. W. Węgrzyniak, Niesprawiedliwy Bóg w Psalmach?, „Verbum Vitae” 26 (2014), s. 16.

Por. J. Ziesler, Sprawiedliwość, w: Słownik wiedzy biblijnej, red. B. M. Metzger, M. D. Coogan, Warszawa 2004, s. 715.
} 
o sprawiedliwości w judaizmie należy odnosić do porządku normatywnego ${ }^{6}$. Administratorami „sprawiedliwości” ustanowieni zostają sędziowie, od których wymaga się uczciwego wykonywania swojej funkcji. Wzorem sędziego jest sam Prawodawca ${ }^{7}$. Poprzez sprawiedliwe sądy zostaje przywrócona utracona przez pogwałcenie Prawa sprawiedliwość ${ }^{8}$.

Kodeksy prawne, jakie możemy znaleźć na kartach Starego Testamentu, regulują bardzo wiele aspektów życia wspólnoty ludu wybranego. Jest to często zbiór luźno ze sobą powiązanych ustaw, gdzie mieszają się przepisy świeckie i religijne. Powoduje to nierzadko zatarcie granicy między prawem karnym i cywilnym a nakazami moralnymi i kulturowymi. W związku z tym, że normom prawnym nadano Boży autorytet, nie było potrzeby ich rozdzielania ${ }^{9}$. Konsekwencją takiego zabiegu jest uznanie absolutnego i wiążącego charakteru Prawa. W odróżnieniu od praw innych ludów kodeksy starożytnego Izraela prezentowane są jako pochodzące od Boga w sposób bezpośredni, spisane „palcem JHWH”" ${ }^{\prime 1}$. Prawo nadane narodowi staje się darem, który pozwala mu poznać wymagania Boga. Tę prawdę wyraża dobrze tekst Księgi Barucha w słowach: „Szczęśliwi jesteśmy, o Izraelu, że znane nam to, co się Bogu podoba" (Ba 4, 4).

Aktem nadania Prawa Bóg zaprasza Izraela do udziału w sprawiedliwości. Samo poznanie woli Bożej to jednak zbyt mało, aby nazwać

\footnotetext{
6 Por. K. Rahner, H. Vorgrimler, Mały słownik teologiczny, tłum. T. Mieszkowski, P. Pachciarek, Warszawa 1996, s. 505-506.

7 Por. S. Rabiej, Sprawiedliwość miara Prawa. Judaistyczne rozumienie sprawiedliwości, w: Wobec sprawiedliwości. Ksiegga dedykowana Janowi Pawłowi II z okazji pobytu Jego Świątobliwości na ziemi gliwickiej, red. S. Rabiej, Opole 1999, s. 45. Ustawodawstwo izraelskie domagało się od sędziów uczciwości podczas wykonywania funkcji (Pwt 1, 16; 16,18. 20; Kpł 19, 15. 36).

8 Por. A. Descamps, Sprawiedliwość, w: Słownik teologii biblijnej, red. X. Leon-Dufour, tłum. K. Romaniuk, Poznań 1994, s. 897-898.

9 Por. A. Tronina, Prawo i sądownictwo, w: Życie społeczne w Biblii, red. G. Witaszek, Lublin 1997, s. 138.

10 Por. E. Zawiszewski, Zagadnienia społeczne w prawodawstwie Starego Testamentu, „Ruch Biblijny i Liturgiczny” 21 (1968) nr 3, s. 139.
} 
człowieka „sprawiedliwym”. Nie wystarcza poznanie i przyjęcie zarządzeń. Potrzebne jest również ich respektowanie, które objawia się przez posłuszeństwo wobec zaleceń. Wykroczenie wobec Prawa nie tylko staje się niesprawiedliwością, lecz jest także winą przeciwko świętości Boga będącego prawodawcą. Dlatego właśnie karą za przekroczenie norm nie jest tylko sąd ludzki, lecz przede wszystkim gniew Boży. Termin „sprawiedliwość” ma więc znaczenie etyczno-religijne. Oznacza postępowanie człowieka, które jest zgodne z wolą Bożą, oraz tego, kto spełnia wymagania Bożych przykazań. Krytykę rzeczywistej drogi Izraela widać wyraziście w pismach prorockich ${ }^{11}$.

\section{Obraz Bożej sprawiedliwości w Biblii}

Nie można rozumieć Bożej sprawiedliwości czysto normatywnie czy stawiać jej na równi z legalizmem prawnym ${ }^{12}$. Takie pojmowanie prowadziłoby do wniosku, że przekroczenie normy prawnej musiałoby zostać osądzone i poddane odpowiedniej dla tego przewinienia karze. Fenomenem wyroków ferowanych przez Boga jest zawarta w nich idea usprawiedliwienia. Pomimo tego, że Jahwe jako prawodawca, wymierzając sprawiedliwość, jest sędzią, to orzeczenia przez Niego wydane mają charakter przede wszystkim pedagogiczny, a nie tylko karny. Bóg bowiem, który jest dobry, nie będzie szukał pomsty. Według zasad czysto prawnych wyroki sądowe, które ujawniają winę oskarżonego, powinny prowadzić do wymierzenia kary ${ }^{13}$. Boża sprawiedliwość przekracza legalizm prawny i dlatego wyrok dla każdego, kto łamie

\footnotetext{
11 Por. M. I. Alves, Przymierze, Dekalog i Ewangelia, „Communio” 13 (1973) nr 1, s. 64-65.

12 Por. A. M. Sicari, Sprawiedliwość Boża w Starym Testamencie, dz. cyt., s. 50.

13 Kodeksy prawne pokazują, jak prawo Izraela ulegało modyfikacjom, kształtowało się w zależności od środowiska i epoki oraz jaki miało związek z religijnym narodu. Prócz dwóch wersji Dekalogu (Wj 20, 2-17; Pwt 5, 6-21) w Pięcioksięgu znajduje się także: Kodeks przymierza (Wj 20, 22 - 23, 33: zawiera sekcję sądów prawa cywilnego i karnego, dotyczy społeczności pasterzy i wieśniaków), Kodeks deuteronomiczny (Pwt 12 - 26: wydaje się być kompilacją praw z różnych epok), Prawo świętości (Kpł 17 - 26:
} 
Prawo, jest łaskawy, usprawiedliwiający tego, kto w skrusze wyzna swoją winę ${ }^{14}$. Chociaż Boża sprawiedliwość ma często związek z karą i gniewem, dużą rolę odgrywa w niej także miłosierdzie ${ }^{15}$. W ten sposób Boża sprawiedliwość staje się sprawiedliwością zbawczą ${ }^{16}$. Gniew i sprawiedliwość Boża wcale nie wyznaczają dwóch kolejnych epok w dziejach ludzkości, ukazują raczej ideę działania Boga, który jest zawsze wierny, zbliża się do prawych i pozwala odejść tym, którzy nie chcą przyjąć i pełnić Jego nakazów ${ }^{17}$.

Obraz Boga miłosiernego można dostrzec wielokrotnie na kartach Starego Testamentu. Pomimo tego, że Bóg Starego Przymierza, jak się wydaje, bardziej ukazuje swoje oblicze sędziego, który karze, nierzadko można dostrzec przekraczającą Prawo postawę Boga litościwego. Przykładem może być postać Salomona, który prosi o okazanie miłosierdzia i wychwala przymioty Boże w słowach: „O Panie, Boże Izraela! Nie ma takiego Boga jak Ty, ani w górze na niebie, ani na dole na ziemi, tak zachowującego przymierze i łaskę względem twoich sług [...]" (1 Krl 8, 22-53), podobnie Micheasz: „Któryż Bóg podobny Tobie, co oddalasz nieprawość, odpuszczasz występek reszcie dziedzictwa Twego? Nie żywi On gniewu na zawsze, bo upodobał sobie miłosierdzie" (Mi 7, 18-20). Warto także zwrócić uwagę na słowa Izajasza (Iz 51, 4-16) czy Barucha (Ba 2, 11 - 3, 8). W czasie, kiedy Bóg odnawia Przymierze $\mathrm{z}$ Izraelem, który po powrocie $\mathrm{z}$ wyganiania prosi o przebaczenie, także zauważamy motyw miłosierdzia (Ne 9). Pisma prorockie szczególnie akcentują sprawiedliwość i miłość jako przymiot Boga (Iz 28, 6; 51, 4-5; 61, 8; Jr 9, 23; 21, 12; Ez 34, 16). On miłuje

\footnotetext{
teksty odwołują się do świętości Boga i Jego ludu, a dominuje obrzędowość i funkcja kapłaństwa) i Kodeks kapłański (Kpł 1 - 7: dotyczy prawa ofiarniczego).

14 Por. A. Descamps, Sprawiedliwość, dz. cyt., s. 904.

15 Por. Słownik symboliki biblijnej. Obrazy, symbole, motywy, metafory, figury stylistyczne i gatunki literackie w Piśmie Świętym, red. L. Ryken, J. C. Wilhoit, T. Longman III, Warszawa 2003, s. 937-938.

16 Por. M. Borda, Prawdziwa sprawiedliwość, „Sosnowieckie Studia Teologiczne” 10 (2011), s. 317-320.

17 Por. X. Leon-Dufour, Słownik Nowego Testamentu, tłum. K. Romaniuk, Poznań 1986, s. 577.
} 
swój lud miłością szczególnego wybrania. Można ją porównać do miłości oblubieńczej (Oz 2, 21-25; Iz 54, 6-8). Bóg przebacza i pozwala człowiekowi na powrót do łaski w momencie, gdy ten przyzna się do swej niewierności. Taka postawa poprowadzi go do nawrócenia (Jr 31, 20; Ez 39, 25-29). Miłosierdzie jest więc potęgą Boga większą niż wykroczenie przeciw Prawu. Lud zwraca się do Boga w poczuciu winy, prosząc o zmiłowanie, ma bowiem przekonanie, że Boża sprawiedliwość przewyższa normatywne rozumienie prawości (2 Sm 11, 12; 24, 10; Ba 3, 2). Miłosierdzie Boga objawiło się również w uwolnieniu ludu z Egiptu (Wj 3, 7-8). Księgi Starego Testamentu zawierają wypowiedzi, z których wyraźnie wynika, że ludzie w sprawiedliwości Bożej dopatrywali się bardziej miłosierdzia niż kary ${ }^{18}$.

Wydaje się, że miłosierdzie Boże najwymowniej zostało przedstawione w Księdze Wyjścia (Wj 34, 6-7), gdzie ukazano różne jego aspekty: „Przeszedł Pan przed jego oczyma i wołał: „Jahwe, Jahwe, Bóg miłosierny i litościwy, cierpliwy, bogaty w łaskę i wierność, zachowujący swą łaskę w tysiączne pokolenia, przebaczający niegodziwość, niewierność, grzech, lecz niepozostawiający go bez ukarania, ale zsyłający kary za niegodziwość ojców na synów i wnuków aż do trzeciego i czwartego pokolenia”. Jest to jedyne miejsce w Starym Testamencie, gdzie sam Bóg mówi o swoim miłosierdziu ${ }^{19}$.

W Nowym Testamencie Jezus jest tym, który wypełnia wszystko, co sprawiedliwe (Mt 3, 15). W ten sposób doprowadza On do szczytu „dawną sprawiedliwość”, wynikającą z legalizmu prawnego. Udział w sprawiedliwość Bożej będzie możliwy dla każdego, kto przekroczy, tak jak Chrystus, normatywne rozumienie Prawa. W ten sposób można powiedzieć, że najwyższym stopniem sprawiedliwości będzie łaska i miłosierdzie, których Bóg udziela człowiekowi. Jezus wielokrotnie krytykuje sprawiedliwość uczonych w Piśmie (oficjalnych

\footnotetext{
18 Por. K. Romaniuk, Sprawiedliwość i miłość jako przymioty Boże, „Ruch Biblijny i Liturgiczny" 17 (1964) nr 1, s. 21.

19 Por. M. Szmajdziński, Miłosierny i łaskawy... Funkcjonowanie synajskiego wyznania wiary (Wj 34, 6-7) w zbiorze dwunastu proroków, w: Oblicza miłosierdzia w Biblii, red. J. Jaromin, Wrocław 2016, s. 72.
} 
interpretatorów norm prawnych) i faryzeuszy (przestrzegających Prawa ściśle co do litery), nazywając ich obłudnikami. Wydaje się, że dezaprobata dotyczy czysto zewnętrznego przestrzegania Prawa oraz dodawania własnych uszczegółowień prawnych, aby być chwalonym przez ludzi (por. Mt 6, 2). Kodeks zawierający dodatkowe nakazy liczył 613 punktów, w których mieściły się przepisy dotyczące rytuałów i zachowań. Przestrzeganie tych praw pozwalało na nazwanie człowieka doskonałym. Jezusowa krytyka nie dotyczyła samych norm: „Czyńcie więc i zachowujcie wszystko, czego was uczą. Nie naśladujcie jednak ich czynów. Mówią bowiem, ale sami nie czynią" (Mt 23, 2-3). Wyraźnie można dostrzec, że większa sprawiedliwość oznacza koherencję słów i czynów, ale przede wszystkim jej kryterium stanowi przykazanie miłości ${ }^{20}$.

\section{Zaproszenie Jezusa do „większej sprawiedliwości” (Mt 5, 20)}

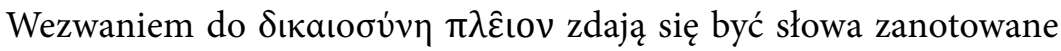
przez ewangelistę Mateusza: „bo powiadam wam: „Jeśli wasza sprawiedliwość nie będzie większa niż uczonych w Piśmie i faryzeuszów, nie wejdziecie do królestwa niebieskiego". Werset ten jest niemal na pewno redakcyjnym uzupełnieniem ewangelisty. Pojęcie obfitości rozumiane

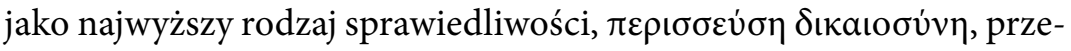
nikało każdy aspekt wczesnego chrześcijaństwa. Przesłaniem perykopy Mt 5, 20 jest wyższa etyka i jeszcze obfitsza sprawiedliwośćc ${ }^{21}$.

Wygłoszone przez Jezusa Kazanie na górze, a szczególnie makaryzmy mają kluczowe znaczenie dla norm etycznych Nowego Testamentu. Niektórzy nazywają tę część Biblii „sercem Ewangelii”22. Wielu

\footnotetext{
20 Por. E. Bosetti, Jeśli chcesz być doskonały. Komentarz do Ewangelii wg św. Mateusza, tłum. P. Majdański, Kraków 2010, s. 187.

21 Głównymi przeciwnikami chrześcijan - wyznawców Jezusa byli w Jamnii i w późniejszym judaizmie rabiniczni spadkobiercy stronnictwa faryzeuszy. Por. Katolicki komentarz biblijny, red. R.E. Brown, J. A. Fitzmyer, R.E. Murphy, Warszawa 2004, s. 929.

22 Por. J. Kudasiewicz, Centralne tematy teologiczno-etyczne Kazania na Górze (Mt 5-6), „Ateneum Kapłańskie” R. 66, t. 77 (1971) z. 1, s. 80.
} 
komentatorów uważa, że Ewangelia Mateusza, która zawiera w swojej treści znamienite mowy Jezusa (Mt $5-7 ; 10 ; 13 ; 18 ; 24 ; 25)$, ma na celu ukazanie idei nowego Prawa. Normy Starego Testamentu zapisane zostały w pierwszych pięciu księgach, zwanych Torą lub Pięcioksięgiem, natomiast Jezus, nadając nowe Prawo, wypowiedział się poprzez swoje pięć mów ${ }^{23}$. W Ewangelii Mateusza dość znacząco rysuje się typologia Mojżesz - Chrystus. Szczególnym tekstem jest Kazanie na górze, gdzie Jezus nosi wyraźne znamiona nowego Mojżesza. Nadanie nowego Prawa jest drogą dla nowego ludu Bożego, który wyrusza do nowej Ziemi Obiecanej. Jezus jest Zbawicielem, a wszelka nowość, jaką przynosi, staje się Mesjańską Torą ${ }^{24}$. Innowacyjne idee głoszone przez Chrystusa nie miały na celu zniesienia wzorca moralnego, jaki odczytujemy u Mojżesza i Proroków. Nauka głoszona przez Jezusa podtrzymuje ideał Prawa Starego Przymierza ${ }^{25}$. Jeszcze wyraźniej można to dostrzec w tekście Mt 5, 17, gdzie mowa jest o tym, że Prawo nie zostanie zniesione. Prócz tego, Jezus w rozmowie $\mathrm{z}$ młodzieńcem, na pytanie: „co mam czynić, aby osiągnąć życie wieczne?”, odpowiada jasno: „zachowaj przykazania" (Mt 19, 16-22; par. Mk 10, 17-22; Łk 18, 18-23). Można dostrzec soteriologiczny aspekt Prawa, nie chodzi tu bowiem o życie w sensie ogólnym, lecz o zbawienie. Prawo Starego Testamentu określone zostało jasno jako słowa życia $(\mathrm{Dz} 7,38)^{26}$.

Rozwój Bożego objawienia charakteryzuje się swoistego rodzaju dynamizmem. Właśnie dlatego zarówno Dekalog, jak i liczne wypowiedzi biblijne dotyczące moralności i prawowierności, stają się drogą objawienia się Boga i jego pełni w Chrystusie. Wcielony Bóg jest „wypełnieniem Prawa” (Mt 5, 17) ${ }^{27}$.

\footnotetext{
23 Por. A. Feuillet, Dwa aspekty sprawiedliwości w Kazaniu na Górze, „Communio” 1 (1981) nr 1-2, s. 72.

24 Por. H. Muszyński, Dziesięć prostych słów Boga zwanych dekalogiem, „Ateneum Kapłańskie" R. 83, t. 117 (1991) z. 2/3, s. 227.

25 Por. A. Feuillet, Dwa aspekty sprawiedliwości..., dz. cyt., s. 68.

26 Por. B. Wodecki, Aspekty soteriologiczne przymierza synajskiego, „Ruch Biblijny i Liturgiczny" 48 (1995) nr 1, s. 9.

27 Por. H. Muszyński, Dziesięć prostych słów Boga..., dz. cyt., s. 224-225.
} 
Niejednokrotnie, jak ukazuje historia Izraela, człowiek dopuszczał się niewierności wobec Bożych praw. Zerwanie przymierza z Bogiem miało smutne konsekwencje w postaci kar, które spadały na naród. Jednak pakt, jaki Bóg zawarł z ludem, charakteryzowała wierność. Prawodawca okazywał ją nawet w momencie niewierności Izraela. Można więc wskazać, że pojęcie Bożej sprawiedliwości znajduje się w tym samym polu semantycznym, co miłosierdzie, ma jednak szerszy zakres znaczeń $^{28}$. Bóg zawsze jest wierny swojemu Przymierzu, inaczej natomiast jest $\mathrm{z}$ człowiekiem. Prorocy $\mathrm{w}$ swoich pismach piętnowali niewierność ludu względem JHWH, jednocześnie zapowiadając Nowe Przymierze (Jr 31, 31-34; zapowiedz nowych zaślubin Oz 2, 20-24; Ez 36, 26; 16, 60; 34, 23; Iz 55, 3). Nowe Przymierze stanie się kontynuacją Starego Przymierza, jednak nie będzie tym samym, zajdzie bowiem ontyczna zmiana. To Jezus wypełni stare Prawo. Zbawczy plan Boga będzie się realizować jako kolejny etap Bożej pedagogii. Właśnie dlatego między Przymierzem pierwszym a Nowym widoczne będą pewne różnice. To, co przyniósł Jezus jako nowe prawo, ma zostać wyryte na ludzkich sercach. Ponadto przymierze zawarte przez Jezusa i w Jezusie charakteryzować będzie zapowiadany przez proroków uniwersalizm (Ez 16, 60-62; Ez 34, 23; Iz 55, 3; Jr 31; Iz 42, 6; 49, 6$)^{29}$. Chrystus odnawia i doprowadza do pełni pakt zawarty na Synaju. Prawo natomiast zostaje streszczone w nakazie miłości Boga i bliźniego ${ }^{30}$. Przykazanie miłości staje się podstawą dla wszelakich norm etycznych płynących z Przymierza Nowego. Ponadto Jezus wyznacza je jako interpretacyjny kanon dla całej Tory.

\section{Natura większej sprawiedliwości}

Perykopa Mateuszowa mówiąca o „większej sprawiedliwości” (Mt 5, 20) stawia nas w obliczu problemów interpretacyjnych. Ich rozwiązania należy szukać w szeroko pojętym kontekście. Konieczne

28 Por. J. Czerski, Biblijne podstawy miłosierdzia, w: Wobec sprawiedliwości..., dz. cyt., s. 43 .

29 Por. B. Wodecki, Aspekty soteriologiczne..., dz. cyt., s. 14.

30 Por. A. Cazzago, Dziesięć prostych słów, „Communio” 13 (1973) nr 1, s. 5. 


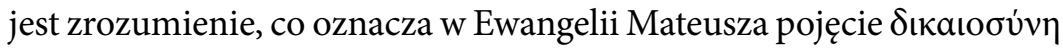
$\pi \lambda \hat{\varepsilon} \iota 0 \vee$ oraz w jaki sposób można je odnieść do sprawiedliwości, która wynika $\mathrm{z}$ przestrzegania Prawa starotestamentalnego. Zagadnienie to można przybliżyć w świetle proroctwa Jeremiasza o nowym przymierzu (Jr 31, 31-34). To przymierze będzie inne niż synajskie. Tekst Jeremiasza dokładnie wskazuje, że owo novum ma polegać na przemianie serca, a nie na dezaktualizacji dotychczasowego Prawa. W wygłoszonym przez Jezusa Kazaniu na górze, dostrzec można potwierdzenie takiego stanu rzeczy: „Nie sądźcie, że przyszedłem znieść Prawo albo Proroków" (Mt 5, 17). Stare Przymierze zawarte na Synaju, zostaje potwierdzone $\mathrm{w}$ Ewangelii i staje się równocześnie moralnym fundamentem Nowego Przymierza we krwi Chrystusa ${ }^{31}$. Prorok Ozeasz w VIII wieku przed Chr., określając nową relację, która tworzy wspólnotę narodu wybranego z Bogiem, podkreślił, że jej fundamentem jest Prawo Boże i wynikająca $z$ jego przestrzegania sprawiedliwość. Zaznacza ponadto, że miłosierdzie Boga dalece przekracza legalne podejście do Prawa ${ }^{32}$. W ten sposób miłość Boga staje się fundamentem dla „większej sprawiedliwości”.

W swojej mowie, Jezus zaraz po słowach o trwałości Prawa $($ Mt 5,17$)$ podaje nauki, które wydają się to prawo zmieniać (Mt 5, 21-48) ${ }^{33}$. Nowa interpretacja Prawa nie zakłada jego zmiany, bo ani jedna jota, ani

31 Por. H. Muszyński, Dziesięć prostych słów Boga..., dz. cyt., s. 226.

32 Por. A. Banaszek, Jezusowy postulat „większej sprawiedliwości”, w: Oto idę: księga pamiątkowa dla Biskupa Profesora Jana Bernarda Szlagi w 65. rocznicę urodzin, zebr. i oprac. W. Chrostowski, Warszawa 2005, s. 87.

33 Mateuszowy tekst relacjonujący wydarzenie Kazania na górze ukazuje pewne problemy wspólnoty, do której został skierowany. W Kościele Mateusza widoczne są dwa trendy myślowe określające poprawne podejście do Prawa. Pierwszy nazywano mianem anomii, co oznacza bezprawie czy nieprawość; definiuje on grupę antynomistów, którzy głosili, że Prawo nie obowiązuje (Mt 7, 23; 13, 41; 23, 28; 24, 12). Przypuszcza się, że byli to chrześcijanie pochodzenia hellenistycznego. Drugą grupę reprezentują natomiast faryzeusze i rabini, którzy bardzo legalistycznie podchodzili do przestrzegania Prawa. Jezus w Kazaniu na górze stanie pomiędzy tymi dwoma nurtami i przedstawi chrześcijańskie rozumienie Prawa. Nie przyszedł bowiem znieść Prawa,

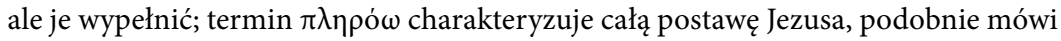
się o wypełnieniu proroctw starotestamentalnych (Mt 1, 22; 2, 15; 4, 14; 8, 17; 12, 17; 
jedna kreska w Prawie się nie zmieni. Chrystus przyszedł po to, aby wypełnić Prawo. Wypełnienie nie może być jednak rozumiane jako ścisła realizacja, jest raczej obrazem zaczerpniętym z życia codziennego ówczesnych czasów. Obraz napełniania naczynia sugeruje ontyczną zmianę. Właściwie chodzi o coś zupełnie nowego. Puste naczynie nie jest tym samym, co pełne, chociaż samo pozostaje tym, czym było ${ }^{34}$.

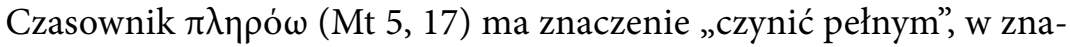
czeniu „doprowadzić do pełni”, „doprowadzić coś do końca” ${ }^{35}$. W tym sensie oznaczałby zarówno „urzeczywistnienie”, czyli „wykonanie” (Mt 23, 23), jak i „czynienie doskonałym”, „udoskonalenie”. Pod pojęciem $\pi \lambda \eta \rho$ ó $\omega$ można także rozumieć „wypełnienie woli Bożej”, co dokonało się poprzez Jezusowe głoszenie Dobrej Nowiny. Czasownik ten nie ma jednak znaczenia „odnawiać” albo „ustanawiać”, co świadczy o tym, że dotychczasowe normy prawne nie zostaną zmienione. Wypełnienie, które przynosi Jezus, doprowadzi Prawo do doskonałości, która winna być rozumiana w sensie ilościowym, jak również jakościowym $^{36}$. Większa sprawiedliwość nie będzie jednak pomnożeniem przepisów prawnych, natomiast ma charakteryzować tych, którzy czyniąc to, co „dobre”, uznali Jezusa i stanęli na drodze do „doskonałości” ${ }^{37}$. Jakościowa zmiana, jaka dokonuje się między tym, co stare i nowe, polega na przesunięciu akcentów. Do tej pory faryzeusze zachowywali wszystkie prawa, a pomimo to Jezus występuje przeciwko ich sprawiedliwości. Sprawiedliwość „większą” będzie charakteryzowała postawa

$13,35 ; 21,4 ; 26,54 ; 26,56)$. Por. J. Kudasiewicz, Centralne tematy teologiczno-etyczne Kazania na Górze (Mt 5-6), dz. cyt., s. 81.

${ }_{34}$ Por. M. Wojciechowski, Czy Jezus żądał zbyt wiele? Objaśnienie Kazania na Górze, Częstochowa 2006, s. 33.

35 Termin ten występuje u Mateusza 16 razy, podczas gdy u Marka 2 razy, a u Łukasza 9 razy. Zob. S. Witkowski, Nowa jakość życia. Kazanie na Górze Mt 5-7, Kraków 2004, s. 61.

36 Por. S. Czyż, Obowiązek zachowania Prawa Starego Testamentu według Mt 5, 17-20, w: Studia $z$ biblistyki, t. 2, red. J. Łach, Warszawa 1980, s. 89-92.

37 Chodzi tu zarówno o Judejczyków, jak i pogan, których można określić mianem „dobrzy”; takie postawy powinny być zauważone, docenione i uznane przez wspólnotę chrześcijańską. 
wewnętrzna, dyspozycja serca. Motywem działania jest wewnętrzne wezwanie do przyjęcia Bożego ojcostwa. Tym samym każdy wybór Ojca pozwoli człowiekowi nazwać się synem, a jego bliźnich braćmi. Jakościowa zmiana winna charakteryzować czyny miłości ${ }^{38}$. Poprzez użycie terminu „wypełnić” zostaje nam wyraźnie ukazane niezmienne Prawo Starego Testamentu, a równocześnie przekroczenie tego, co było Starym Przymierzem i otwarcie perspektywy widzenia nowości, którą przyniósł Jezus (Mt 3, 15).

Żydowscy nauczyciele, mówiąc o znoszeniu Prawa, mieli na myśli okazywanie braku posłuszeństwa wobec jego nakazów (Pwt 27, 26). $\mathrm{W}$ ten sposób zostałby usunięty autorytet Prawa ${ }^{39}$. Jezus wyraźnie wskazuje, że nie przychodzi po to, aby znieść Prawo (Mt 5, 17). Na kartach Biblii widzimy wyraźnie, że Prawo jest przez Jezusa zachowywane (J 2, 13; 5, 2; 7, 10; Mt 21, 12; 23, 23). Chrystus nie przeciwstawia się też Mojżeszowi (Mk 7, 10; Mt 15, 4; Mk 12, 26; Mt 22, 31). Zarówno On sam, jak i Jego uczniowie, wiedzieli w Prawie objawienie się woli Bożej (J 8, 5; Mk 10, 3). Wyraźnie trzeba jednak odróżnić Boże nakazy i zakazy od czysto ludzkich norm, które w judaizmie przenikały się wzajemnie. Ponadto zaakcentowanie Boga jako Prawodawcy doprowadziło naród izraelski do sztywnego legalizmu. W ten sposób stanęły naprzeciw siebie dwa wymiary przestrzegania prawa: jeden czysto zewnętrzny, a drugi wewnętrzny, propagowany przez Jezusa. Istniało przekonanie, że gorliwością w przestrzegania Prawa można nadrobić braki moralne (Mt 23, 1-7; 15, 1-20). Czysty legalizm oraz żydowskie tradycje zostają przez Chrystusa potępione ${ }^{40}$, jako prowadzące do lekceważenia Bożych zasad (Mk 12, 28-34). Pomimo tego, że Jezus broni

\footnotetext{
38 Por. A. Paciorek, Ewangelia według świętego Mateusza, rozdziały 1 - 13. Wstęp, przekład z oryginału, komentarz, Częstochowa 2005, s. 234 (Nowy Komentarz Biblijny. Nowy Testament, t. 1, cz. 1).

39 Por. C. S. Keener, Komentarz historyczno-kulturowy do Nowego Testamentu, tłum Z. Kościuk, Warszawa 2000, s. 18.

40 Zasady zwyczajowe, jakie zostały narzucone przez rabinów (tradycja starszych: Mk 7, 5), i przepisy pochodzące wyłącznie od ludzi (tradycja ludzka: Mk 7, 8) zostają ukazane w opozycji do Bożych przykazań, prawa pisanego i tradycji ustnej. Por. S. Czyż, Obowiązek zachowania Prawa Starego Testamentu..., dz. cyt., s. 97.
} 
autorytetu Prawa, daje do zrozumienia, że samo zachowanie Prawa to za mało. Uczeń Chrystusa winien prezentować wyższą doskonałość, opartą na wierze w Chrystusa i wierności Chrystusowi. Sprawiedliwość większa nie polega jednak na tym, aby do Prawa dodawać dodatkowe doskonałości, jak to robili faryzeusze, podnosząc swoje czyny ponad doskonałość ${ }^{41}$. Orędzie Nowego Przymierza zwraca szczególną uwagę na dyspozycję serca ${ }^{42}$.

Wziąć udział w Bożej sprawiedliwości oznacza pełnić czyny miłosierdzia. Bóg wręcz nakazuje człowiekowi bycie miłosiernym, natomiast tych, którzy nie podejmą się wypełnienia tego nakazu, czeka wyrok sprawiedliwości (Mt 25, 41-43). Miłosierdzie w tej perspektywie staje się wyznacznikiem „większej sprawiedliwości”. Tam, gdzie brak miłosierdzia, tam też nie zostaje wypełniony postulat sprawiedliwości ${ }^{43}$.

\section{Bibliografia}

Alves M. I., Przymierze, Dekalog i Ewangelia, „Communio” 13 (1973) nr 1, s. 62-71.

Banaszek A., Jezusowy postulat „większej sprawiedliwości”, w: Oto idę: księga pamiątkowa dla Biskupa Profesora Jana Bernarda Szlagi w 65. rocznicę urodzin, zebr. i oprac. W. Chrostowski, Warszawa 2005, s. 77-93.

Barnett P.W., Przeciwnicy Pawła, w: Słownik teologii Świętego Pawła, red. G.F. Hawthorne, R.P. Martin, D.G. Reid, Warszawa 2010, s. 664-665.

Borda M., Prawdziwa sprawiedliwość, „Sosnowieckie Studia Teologiczne” 10 (2011), s. 317-320.

Bosetti E., Jeśli chcesz być doskonały. Komentarz do Ewangelii wg św. Mateusza, tłum. P. Majdański, Kraków 2010.

Cazzago A., Dziesięć prostych słów, „Communio” 13 (1973) nr 1, s. 3-9.

\footnotetext{
41 Por. E. Staniek, Kazanie na górze, Kraków 2003, s. 56-57.

42 Terminu „serce” ewangelista używa zazwyczaj w znaczeniu przenośnym (Mt 5, 8; $5,28 ; 6,21 ; 9,4 ; 11,29 ; 12,34 ; 12,19 ; 15,8 ; 16,18 ; 18,35 ; 22,37)$.

43 Por. R. Forycki, Miłosierdzie nakazem sprawiedliwości, „Communio” 1 (1981) nr 1-2, s. 84-85.
} 
Czerski J., Biblijne podstawy miłosierdzia, w: Wobec sprawiedliwości. Księga dedykowana papieżowi Janowi Pawłowi II z okazji pobytu Jego Świątobliwości na ziemi gliwickiej, red. S. Rabiej, Opole 1999, s. 31-43.

Czerski J., Literatura epistolarna Nowego Testamentu. Część 1: Listy protopawłowe, Opole 2014 (Opolska Biblioteka Teologiczna, 132).

Czyż S., Obowiazek zachowania Prawa Starego Testamentu wedtug Mt 5, 17-20, w: Studia $z$ biblistyki, t. 2, red. J. Łach, Warszawa 1980, s. 89-92.

De Voux R., Instytucje Starego Testamentu, t. 1 i 2, tłum. T. Brzegowy, Poznań 2004.

Descamps A., Sprawiedliwość, w: Słownik teologii biblijnej, red. X. Leon-Dufour, tłum. K. Romaniuk, Poznań 1994, s. 897-898.

Feuillet A., Dwa aspekty sprawiedliwości w Kazaniu na Górze, „Communio” 1 (1981) nr 1-2, s. 67-75.

Forycki R., Miłosierdzie nakazem sprawiedliwości, „Communio” 1 (1981) nr 1-2, s. 77-86.

Grzybek S., Finis Legis Christus (Rz 10, 4), „Ruch Biblijny i Liturgiczny” 14 (1961) nr 5, s. 181-189.

Kaiser W.C., Davids P.H., Bruce F.F., Brauch M.T., Trudne fragmenty Biblii, konsultacja naukowa wydania polskiego W. Chrostowski, Warszawa 2011, s. 281-284.

Katolicki komentarz biblijny, red. R.E. Brown, J.A. Fitzmyer, R.E. Murphy, pol. red. nauk. W. Chrostowski, Warszawa 2004.

Keener C.S., Komentarz historyczno-kulturowy do Nowego Testamentu, tłum Z. Kościuk, Warszawa 2000.

Kudasiewicz J., Centralne tematy teologiczno-etyczne Kazania na Górze (Mt 5-6), „Ateneum Kapłańskie” R. 63, t. 77 (1971) z. 1, s. 80-91.

Leon-Dufour X., Słownik Nowego Testamentu, tłum. K. Romaniuk, Poznań 1986. Łach S., Znaczenie wyrażenia Tôrāh w Psatterzu, „Ruch Biblijny i Liturgiczny” 28 (1975) nr 4-5, s. 151-159.

Mróz M., „Non repulit Deus plebem suam”. Wykład św. Tomasza z Akwinu na temat miary Bożej mądrości względem "gens iudaeorum” wświetle „Expositio super Epistolam ad Romanos (cap. IX-XI)”, „Collectanea Theologica” 75 (2005) nr 2, s. 57-82.

Muszyński H., Dziesięć prostych słów Boga zwanych dekalogiem, „Ateneum Kapłańskie" R. 83, t. 117 (1991) z. 2/3, s. 221-234. 
Muszyński H., Kresem Prawa jest Chrystus (Rz 10, 4). Aktualność norm religijno-moralnych Starego Testamentu, „Studia Theologica Varsaviensia” 28 (1990) nr 2, s. 26-37.

Paciorek A., Człowiek bez Chrystusa w soteriologii Listu św. Pawła do Rzymian, Tarnów 1995.

Paciorek A., Ewangelia według świętego Mateusza, rozdziały 1 - 13. Wstęp - przekład z oryginału - komentarz, Częstochowa 2005 (Nowy Komentarz Biblijny, Nowy Testament, t. 1, cz. 1).

Pindel R., Poznać Pawła Apostoła. Lektura wybranych fragmentów Dziejów Apostolskich i Listów św. Pawła, Kraków 2008.

Rabiej S., Sprawiedliwość miarą Prawa. Judaistyczne rozumienie sprawiedliwości, w: Wobec Sprawiedliwości. Księga dedykowana Janowi Pawłowi II z okazji pobytu Jego Świątobliwości na ziemi gliwickiej, red. S. Rabiej, Opole 1999, s. 45-51.

Rahner K., Vorgrimler H., Sprawiedliwość, w: Mały słownik teologiczny, tłum. T. Mieszkowski, P. Pachciarek, Warszawa 1996, s. 505-506.

Romaniuk K., List św. Pawła do Rzymian. Wstęp - przekład z oryginału - komentarz, Poznań 1978 (Pismo św. Nowego Testamentu, t. 6, cz. 1).

Romaniuk K., Sprawiedliwość i miłość Jako przymioty Boże, „Ruch Biblijny i Liturgiczny" 17 (1964) nr 1, s. 19-24.

Sicari A.M., Sprawiedliwość Boża w Starym Testamencie, „Communio” 1 (1981) nr 1-2, s. 49-64.

Słownik symboliki biblijnej. Obrazy, symbole, motywy, metafory, figury stylistyczne i gatunki literackie $w$ Piśmie Świętym, red. L. Ryken, J. C. Wilhoit, T. Longman III, tłum. Z. Kościuk, Warszawa 2003.

Staniek K. E., Kazanie na górze, Kraków 2003.

Szmajdziński M., Miłosierny i łaskawy... Funkcjonowanie synajskiego wyznania wiary (Wj 34, 6-7) w zbiorze dwunastu proroków, w: Oblicza miłosierdzia $w$ Biblii, red. J. Jaromin, Wrocław 2016, s. 71-95.

Tronina A., Prawo i sądownictwo, w: Życie społeczne w Biblii, red. G. Witaszek, Lublin 1997, s. 133-147.

Węgrzyniak W., Niesprawiedliwy Bóg w Psalmach?, „Verbum Vitae” 26 (2014), s. $15-32$.

Witkowski S., Nowa jakość życia. Kazanie na Górze Mt 5-7, Kraków 2004.

Wodecki B., Aspekty soteriologiczne przymierza synajskiego, „Ruch Biblijny i Liturgiczny" 48 (1995) nr 1, s. 1-17. 
Wojciechowski M., Czy Jezus żądał zbyt wiele? Objaśnienie Kazania na Górze, Częstochowa 2006.

Zawiszewski E., Zagadnienia społeczne w prawodawstwie Starego Testamentu, „Ruch Biblijny i Liturgiczny” 21 (1968) nr 3, s. 139-146.

Ziesler J., Sprawiedliwość, w: Słownik wiedzy biblijnej, red. B. M. Metzger, M. D. Coogan, Warszawa 2004, s. 715-716.

\section{Streszczenie}

Artykuł jest próbą odpowiedzi na pytanie o naturę sprawiedliwości. Opierając się na metodzie kanonicznej, można stwierdzić, że termin „sprawiedliwość" w Biblii znacznie przekracza normatywny porządek prawny, ponieważ posiada trwały aspekt religijno-moralny. Wsparciem tego założenia są słowa Jezusa

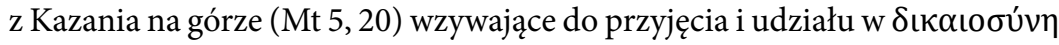
$\pi \lambda \hat{\varepsilon} \iota$ ( (większej sprawiedliwości), która zawiera w sobie paradygmat miłości. Dotychczasowe rozumienie Prawa zostaje podporządkowane przykazaniu miłości. Charakterystyką nowej interpretacji norm prawnych jest Boże miłosierdzie, które przekracza legalizm Prawa, gdyż miłość staje się fundamentem „większej sprawiedliwości”.

Słowa kluczowe sprawiedliwość, prawo, miłość, Jezus

\section{Summary}

\section{The relationship of legal legality to God's justice in the light of Mt 5:20}

The article is an attempt to answer the question about the nature of justice. Based on the canonical method it can be clearly stated that the term "justice" in the Bible exceeds by far the normative legal order because it has a permanent religious and moral aspect. This assumption is supported by the words of Jesus from the Sermon on the Mount (Mt 5:20) calling

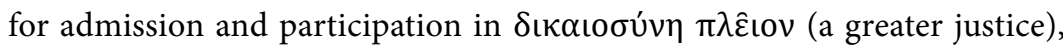
which includes the paradigm of love. The current understanding of the Law is subordinated to the commandment of love. A characteristic of the new 
interpretation of Legal norms lays in God's mercy, which exceeds by far the legalism of the Law, because it is love that becomes the foundation of "a greater justice."

Keywords Justice, Law, Charity, Jesus Christ 
A. Uniwersytet Papieski

Ifét Jana Pawła II

o. W Krakowie 